\title{
Implementasi Digital Smart Care pada Kader Kesehatan sebagai Upaya Pencegahan Stunting
}

\author{
Annah Hubaedah, Yuni Khoirul Waroh, Anik Latifah \\ Email: annahhubaedah@unipasby.ac.id \\ DIII Kebidanan, Universitas PGRI Adi Buana Surabaya, Indonesia \\ J1. Dukuh Menanggal XII/4 Surabaya \\ Telp/Fax. (031) 8281181
}

\begin{abstract}
Abstrak
Pengabdian Pada Masyarakat (PPM) ini dilaksanakan di kelurahan Siwalankerto, Kecamatan Wonocolo, Kotamadaya Surabaya dengan judul “ Implementasi Digital Care Pada Kader Kesehatan Sebagai Upaya Pencegahan Stunting”, yang bertujuan untuk menurunkan angka kejadian stunting dengan cara meningkatkan pengetahuan dan juga keterampilan kepada masyarakat khususnya Ibu Balita, Kader Posyandu, serta PKK di wilayah Kelurahan Siwalankerto melalui penggunaan Digital Care. Dari hasil studi pendahuluan didapatkan data jumlah balita di Siwalankerto tahun 2019, 1.010 jiwa, balita kurang gizi 25 anak. Melihat kondisi tersebut maka dibutuhkan solusi untuk mengatasi masalah pada Balita, terutama yang berkaitan dengan stunting. Metode yang digunakan dalam Pengabdian Pada Masyarakat ini adalah penggunaan Digital Care. Sasarannya adalah: ibu Balita, Kader Posyandu, serta PKK di wilayah Kelurahan Siwalankerto. Harapan hasil kegiatan PPM adalah meningkatkan pengetahuan, dan keterampilan dalam pencegahan stunting.
\end{abstract}

Kata kunci: balita; implementasi; digital care; stunting.

\begin{abstract}
This Community Service (PPM) was carried out in Siwalankerto Village, Wonocolo District, Surabaya Municipality with the title "Implementation of Digital Care for Health Cadres as Stunting Prevention Efforts", which aims to reduce the incidence of stunting by increasing knowledge and skills for the community, especially mothers. Toddlers, Posyandu Cadres, and PKK in Siwalankerto Urban Village through the use of Digital Care. From the results of the preliminary study, data on the number of toddlers in Siwalankerto in 2019, 1,010 people, 25 children with malnutrition. Seeing this condition, a solution is needed to overcome problems in toddlers, especially those related to stunting. The method used in this Community Service is the use of Digital Care. The targets are: toddler mothers, Posyandu cadres, and PKK in the Siwalankerto Village area. The hope of the results of PPM activities is to increase knowledge and skills in preventing stunting.
\end{abstract}

Keywords: toddlers, implementation, digital care, stunting

\section{Pendahuluan}

Gizi yang berkualitas adalah penentu keberlangsungan hidup, kesehatan, dan pertumbuhan anak. Anak yang bergizi baik dapat bertumbuh dan belajar, berpartisipasi dan bermanfaat bagi masyarakat, dan mampu bertahan saat menghadapi tantangan penyakit, bencana alam dan bentuk lain dari krisis global ${ }^{[1]}$

Stunting merupakan kondisi dimana tinggi badan balita lebih pendek dibandingkan dengan balita yang lain pada umur yang sama. Ada beberapa penyebab stunting yaitu gizi buruk yang dialami sejak hamil maupun pada balita, kurangnya 
pengetahuan orang tua mengenai kesehatan dan gizi, masih terbatas layanan kesehatan yang berkualitas, masih kurangnya akses kepada makanan bergizi, kurangnya akses ke air bersih dan sanitasi. Dampak stunting pada balita dibagi dalam 2 kategori, yaitu jangka pendek dan jangka panjang. Dampak jangka pendek bisa adanya gangguan pada perkembangan otak, kecerdasan, gangguan pertumbuhan fisik, serta gangguan metabolism dalam tubuh. Sedangkan dampak jangka panjang seperti menurunnya kemampuan kognitif dan prestasi belajar, menurunnya system imun tubuh (kekebalan), dan resiko tinggi terjadinya diabetes mellitus, penyakit jantung, obesitas, kanker, stroke dan disabilitas pada usia lanjut . ${ }^{[2]}$

Menurut Riset Kesehatan Dasar (Riskesdas) Indonesia tahun 2018, didapatkan data bahwa 29,9 persen anak di bawah usia 24 bulan mengalami bentuk-bentuk stunting, Proporsi status gizi balita di Jawa Timur; gizi buruk dan gizi kurang $( \pm 16,78 \%)$, sangat pendek dan pendek $( \pm 32,81 \%)$. Dan Proporsi status gizi baduta di Jawa Timur sangat pendek $( \pm 15 \%)$ dan pendek $( \pm 32 \%)[5]$. Hasil Riset Kesehatan Dasar (Riskesdas) Surabaya tahun 2018, proporsi status gizi buruk dan gizi kurang (14\%), Proporsi status gizi sangat pendek dan pendek $(30 \%){ }^{[3]}$

Luas wilayah Siwalankerto 1,98 $\mathrm{km} 2$, dengan ketinggian wilayah $9 \mathrm{~m}$ dari permukaan laut. Jumalah RT 38 dengan jumlah 6 RW. Jumlah penduduk 17.683 jiwa, dengan kepadatan penduduk 8.931 jiwa/km2. Jumlah KK 5.491; bekerja 4.565, tidak bekerja 926. Tingkat pendidikan Kepala Keluarga : tidak tamat SD 160, Tamat SD, SLTP 927, Tamat SLTA 3.851, Tamat akademik/Universitas 553. Fasilitas kesehatan di Siwalankerto; poskeskel 1 , posyandu 18 , dan posyandu lansia 4. Jumlah balita di Siwalankerto tahun 2018, 1.010 jiwa, dan balita gizi kurang sebanyak 24 anak. Stunting mencerminkan kekurangan gizi kronis dan dapat menimbulkan dampak jangka panjang, antara lain hambatan pertumbuhan, penurunan kemampuan kognitif dan mental, kerentanan terhadap penyakit, produktivitas ekonomi rendah dan kualitas reproduksi rendah. ${ }^{[4]}$

Penggunaan internet pada era revolusi 4.0 merupakan hal yang sangat lazim digunakan untuk membantu pemenuhan kebutuhan manusia. Dalam dunia kesehatan penggunaan Digital smart care juga cukup banyak membantu, apalagi di era pandemi seperti saat ini, untuk mengurangi sentuhan fisik antar manusia. ${ }^{[5]}$

Inilah menjadikan dasar pemikiran Tim PPM Prodi D III Kebidanan Fakultas Sains dan Kesehatan Universitas PGRI Adi Buana Surabaya menjadikan Kelurahan Siwalankerto sebagai tempat untuk PPM dengan mencoba membantu menurunkan dan mengatasi masalah stunting yang ada di wilayah Kelurahan Siwalankerto.

\section{Metode}

Kegiatan Pengabdian Pada masyarakat ini menggunakan 4 tahap, yang terdiri dari: Sosialisasi program pengabdian pada masyarakat, tahap pelaksanaan, tahap pelaksanaan, dan tahap evaluasi

Sosialisasi dilakukan dengan koordinasi dengan pembuat kebijakan (Bangkesbangpolitmas, Dinas Kesehatan kota Surabaya, Kecamatan Wonocolo, Kelurahan Siwalankerto dan Puskesmas Siwalankerto). Dilanjutkan dengan sosialisasi dan koordinasi waktu, tempat, dan sasaran program PPM 
dalam hal ini Kader PKK dan Kader Posyandu.

Tahap Persiapan dilakukan dengan cara melakukan identifikasi /mendata jumlah balita, mempersiapakan tempat dan sarana pelaksanaan pelatihan Implementasi Digital Smart Care, dan yang terakhir mempersiapkan materi, alat bantu Digital Smart Care (HP) dan jadwal pelaksanaan serta materi yang akan disampaikan.

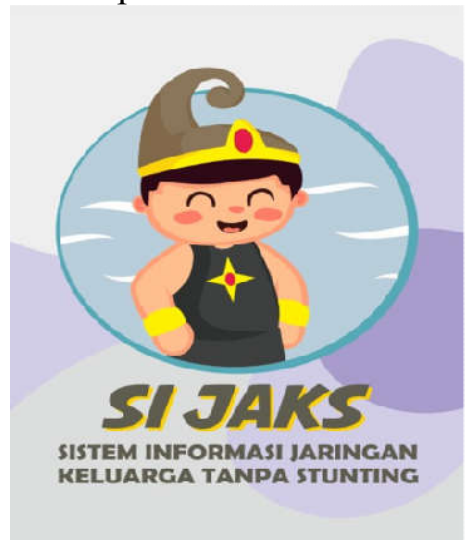

Tahap pelaksanaan dengan menggunakan Workshop penggunaan Digital Smart Care pada deteksi dini stunting yang diharapkan terjadi perubahan perilaku masyarakat.

Tahap evaluasi dengan memantau perkembangan dan dampak pelaksanaan pelatihan penggunaan Digital Smart Care dalam mendeteksi dini stunting dengan bekerjasama dengan stakeholder.

\section{Hasil dan Pembahasan}

Pada tahap pelaksanaan workshop dihadiri oleh 15 kader posyandu di RW 5 Kelurahan Siwalankerto, Kecamatan Wonocolo, Kota Surabaya. Dari hasil workshop para kader posyandu melakukan sosialisasi penggunaan Digital Smart Care pada para ibu balita di posyandu masing-masing. Dimana peserta workshop sangat antusias dalam mengikuti kegiatan dan mampu menularkan ilmu yang didapat kepada ibu balita di posyandu masing-masing . Tahap pelaksanaan terdiri dari:

a. Sosialisasi

Pada tahap sosialisasi dihadiri ibu-ibu kader posyandu di RW 5 yang beragendakan pemaparan penggunaan Digital Smart Care dalam hal ini menggunakan aplikasi SIJAKS, yang dimana para ibu kader sangat antusias karena mendapatkan ilmu baru untuk mendeteksi pertumbuhan dan perkembangan anak Balita.

b. Implementasi

Pada tahap ini para kader posyandu diminta untuk mengaplikasikan penggunaan Digital Smart Care dalam hal ini SIJAKS sebelum mensosialisasikan ke ibu-ibu posyandu di wilayahnya.

Menurut Soekidjo, N ( 2012) menyatakan pendidikan kesehatan diberikan kepada masyarakat agar masyarakat menyadari atau mengetahui bagaimana cara memelihara keseharan mereka, bagaimana menghindari atau mencegah hal-hal yang merugikan kesehatan mereka dan kesehatan orang lain.

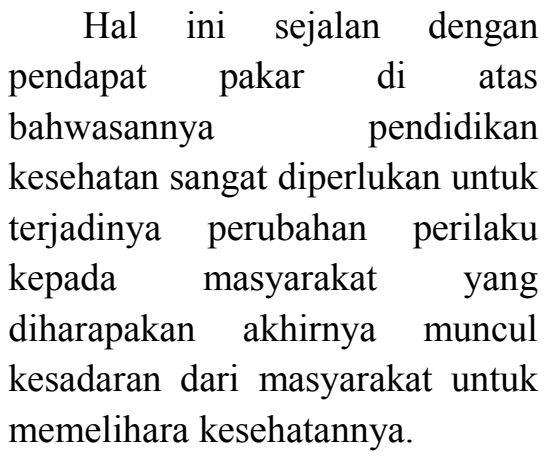


c. Evaluasi

Tahap evaluasi digunakan untuk mengetahui sejauh mana para kader posyandu mengerti dan dapat mengimplementasikan penggunaan SIJAKS pada ibu-ibu posyandu di wilayahnya. Didapatkan hasil sebagian besar ibu-ibu bisa menggunakan aplikasi SIJAKS untuk mendeteksi pertumbuhan dan perkembangan anak Balita.

Gambar 1. Kegiatan Pelaksanaan PPM

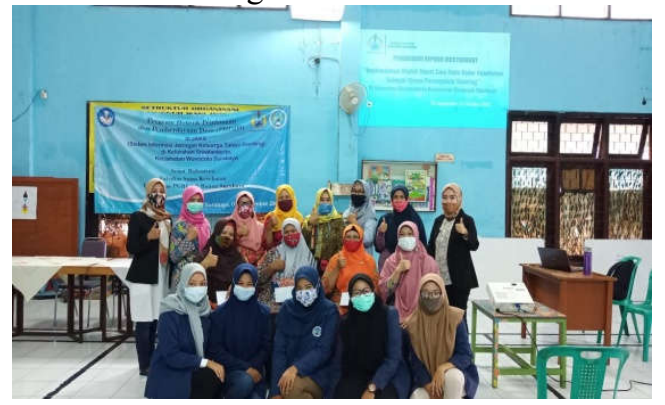

Gambar 2. Kader Posyandu

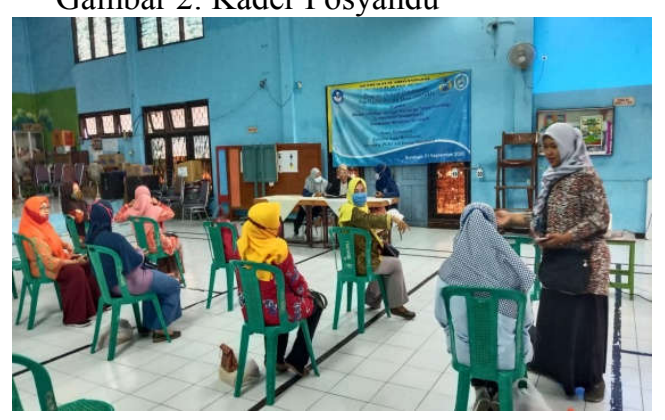

Gambar 3. Pemberian Cendera mata

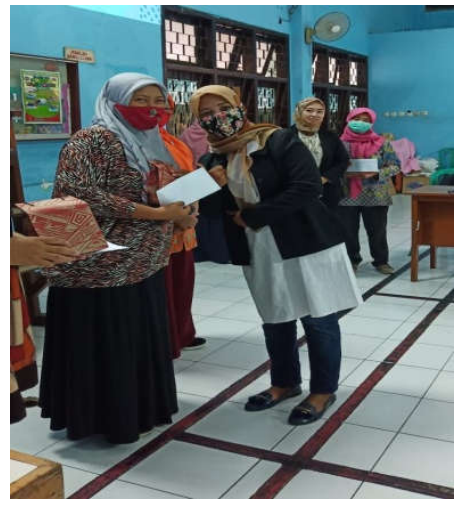

4. Kesimpulan

Kesimpulan dari kegiatan Pengabdian Pada Masyarakat ini adalah terjadi perubahan perilaku pada kader posyandu dan ibu balita dalam mendeteksi adanya gangguan pada pertumbuhan anak balita dengan menggunakan Digital Smart Care dalam hal ini menggunakan aplikasi SIJAKS. Dimana terjadi perubahan perilaku yaitu penggabungan Behaviour Communication Change (BCC), yaitu proses interaktif antara individu, kelompok atau masyarakat dalam mengembangkan strategi komunikasi dan Bevavior Intention dimana perilaku seseorang atau masyarakat ditentukan oleh niat orang terhadap obyek kesehtan, adanya dukungan dari masyarakat sekitarnya, ada informasi tentang kesehatan sehingga menimbulkan perubahan perilaku.

\section{Daftar Pustaka}

[1] P. D. tertinggal dan T. Kementerian desa (2017). Buku Saku Desa dalam "Penanganan Stunting".

[2] UNICEF, Situasi Anak di Indonesia - Tren, Peluang, dan Tantangan dalam Memenuhi Hak-hak Anak, 2020. 
[3] Riskesdas 2018, "HASIL UTAMA RISKESDAS 2018 Kesehatan," pp. 20-21, 2018.

[4] B. P. Statistik, Wonocolo dalam angka 2019. p.2554.

[5] K. Klinker, M. Wiesche, and H. Krcmar, "Digital Transformation in Health Care: Augmented Reality for Hands-Free Service Innovation," Inf. Syst. Front., vol.22, no.6, 2020, doi: 10.1007/s10796-019-09937-7.

[6] Soekidjo, Notoatmodjo, Promosi Kesehatan dan Perilaku Kesehatan, Jakarta: Rineka Cipta, 2012 